В.С. Яровий ${ }^{1}$, Г.Д. Радзівілов ${ }^{1}$, С.В. Герасимов ${ }^{2}$, В.В. Кірвас ${ }^{2}$

${ }^{1}$ Військовий інститут телекомунікацій та інформатизаџії ім. Героїв Крут, Київ

${ }^{2}$ Харківський національний університет Повітряних Сил ім. І. Кожедуба, Харків

\title{
ДІАГНОСТИКА НЕСПРАВНОСТЕЙ ВИПРЯМНИХ ТРАНСФОРМАТОРІВ ВИСОКОЧАСТОТНИХ ДЖЕРЕЛ ЖИВЛЕННЯ НА ОСНОВІ ВИЗНАЧЕННЯ ОСОБЛИВОСТЕЙ СТРУМУ
}

Досліджуються особливості виявлення несправностей випрямних трансформаторів високочастотних джерел живлення. Показано, щео випрямні трансформатори є ключовими компонентами високочастотних джерел живлення. Обгрунтовано, шо форми хвиль випрямних трансформаторів відіграють важливу роль у діагностииі несправностей джерел живлення високої частоти. Мета статті полягає у вдосконаленні методу діагностики несправностей випрямних трансформаторів високочастотних джерел живлення. Запропонований метод використовує функиї для опису системи технічного стану випрямних трансформаторів високочастотних джерел живлення та реалізує вимоги до класифікаторів несправностей. За допомогою розроблених класифікаторів несправностей випрямних трансформаторів високочастотних джерел живлення несправності можуть бути оперативно виявлені та локалізовані.

Ключові слова: діагностика несправностей, високовольтне джерело живлення високої частоти, вибір функиії, моніторинг.

\section{Вступ}

Постановка проблеми. Зазвичай в діагностиці несправностей випрямного трансформатора аналізується інтегральне значення поточної форми хвилі. Однак на форми хвиль струмів суттєво впливає навантаження, що в поєднанні з несправностями призводить до ускладнення процесу діагностики технічного стану. Як правило, звичайні методи не можуть 3 високою точністю визначити ймовірні несправності в зв'язку з високими похибками. Для отримання даних про особливості несправностей у цьому дослідженні були проаналізовані первинні та вторинні форми хвиль струмів. Отримані дані були використані для навчання векторних машин 3 підтримкою найменших квадратів для створення класифікаторів несправностей, таким чином реалізувавши виявлення несправностей та розподіл випрямного трансформатора. Запропонований метод застосовувався до фактичних даних про форму хвилі одної з електростанцій, що дало змогу провести дослідження.

Аналіз останніх досліджень і публікацій. У електроенергетиці, металургії, нафтовій, хімічній, цементній та інших галузях промисловості широко використовуються високочастотні джерела живлення для електростатичних фільтрів (ESPs), з метою підвищення ефективності видалення пилу [1]. Високочастотне джерело живлення випрямлює трифазну вхідну потужність промислової частоти в постійний струм, який потім перетворюється ланцюгом перетворювача (інвертора) у високочастотний змінний струм на частотах понад 10 кГц. Після того, як високочастотний трансформатор збільшує напругу та вихідний випрямляч струму завершує фільтрацію, до частотних джерел електроживлення подається високочастотний пульсуючий струм.

Високочастотне джерело живлення складається 3 вхідного фільтруючого випрямляча, схеми перетворювача, високочастотного трансформатора та високовольтної випрямної схеми. Як ключовий компонент, продуктивність високочастотного трансформатора безпосередньо впливає на продуктивність всієї системи електропостачання. На рис. 1 зображено основну структуру високочастотного джерела живлення.

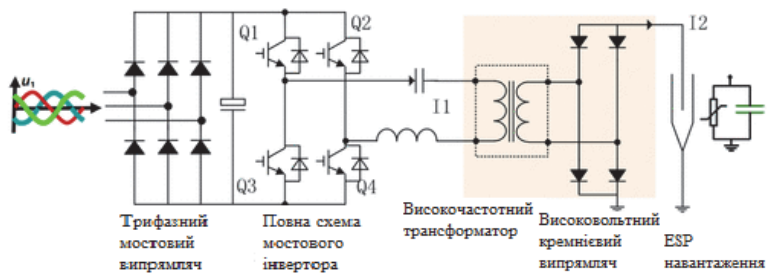

Рис. 1. Основна структура високочастотного джерела живлення

Джерело: розроблено авторами.

Високочастотні трансформатори зазвичай масляні. Оскільки трансформатор і вихідний випрямляч розміщені в одному занурювальному баку, газ, розчинений у маслі, неможливо виміряти в режимі реального часу. Отже, підхід на основі трьох співвідношень Міжнародної електротехнічної комісії (IEC) 60599 [2-3], який вимагає точної інформації про розчинений газ і $є$ класичним методом традиційної діагностики трансформаторів, не підходить для діагност ування цього прист рю. Таким чином, необхідний альтернативний підхід. 
Єдиним способом вирішення цієї задачі є діагностика несправностей за допомогою аналізу форми хвилі. Для діагностики несправностей випрямного трансформатора в інженерних програмах зазвичай використовуються інтегральні значення первинного та вторинного струму трансформатора [4-6]. Однак цей показник не дає достатньої інформації для опису несправностей з'єднання, і це часто призводить до недостовірних результатів діагностики. Для покращення ефективності процесу діагностики показників високочастотних джерел живлення [7-10] потрібен більш ефективний спосіб виявлення ознак несправностей.

Мета статті - вдосконалення методу для діагностики несправностей випрямних трансформаторів високочастотних джерел живлення.

Основними завданнями статті $є$ наступне.

1. Підвищення точності діагностики. Оскільки в діагностиці реалізуються нелінійні класифікатори, джерела живлення, що розглядаються, не можуть бути коректно продіагностовані традиційним інтегральним значенням, доцільніше продіагностувати їх запропонованим методом.

2. Визначення властивостей з поточних форм хвиль за допомогою спеціально розробленого мето$\partial y$. У порівнянні з традиційним методом на основі інтегральних значень, запропонований метод надає набагато більше інформації для діагностики. Порівняно із загальним методом визначення ознак, таким як розкладання пакетів вейвлетів (WPD) та максимально корельована деконволюція Куртоза (MCKD), запропонований метод більш доступний і вимагає менше часу на обчислення.

\section{Виклад основного матеріалу}

Перегрівання або розряд може призвести до того, що ізолююче трансформаторне масло буде виробляти різні компоненти газу. Традиційно несправності трансформаторів можна діагностувати за допомогою аналізу розчиненого газу (DGA), як і в трьох співвідношеннях, які було запропоновано IEC у 1978 році та переглянуто у 2008 році [2]. Але для високочастотних джерел живлення, так як трансформатор і вихідний випрямляч розміщені у одному і тому ж занурювальному баку, підходи DGA не підходять. На це є дві причини. Перша полягає в тому, що перегрів або розряд від різних пристроїв, таких як трансформатори або випрямлячі, можуть створювати однакові компоненти газу. Друга полягає в тому, що розчинений газ не може бути виміряний в режимі реального часу.

Таким чином, в інженерних програмах контролюються струми первинної та вторинної форми хвиль для аналізу стану випрямного трансформатора. Як показано на рис. 2, під час нормальної роботи суміжні форми хвиль первинного струму рівні за величиною та протилежні за напрямом, тоді як форми хвиль вторинного струму мають однакову величину та напрямок. Тому інтегральні значення двох суміжних форм хвиль повинні мати однакове абсолютне значення.

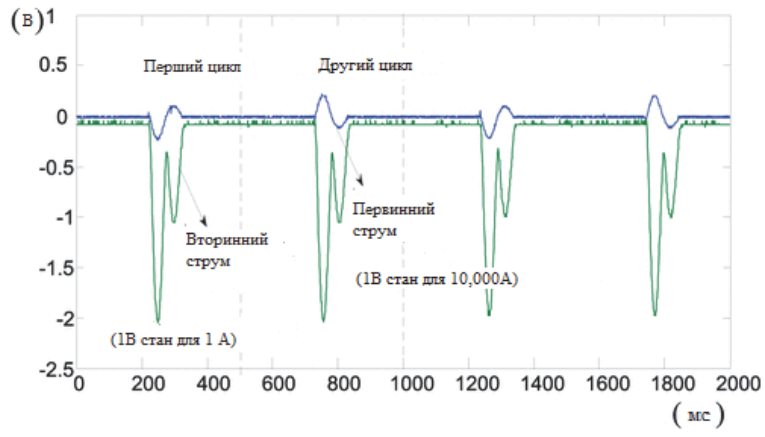

Рис. 2. Нормальна форма хвилі Джерело: розроблено авторами.

Коли компонент системи виходить з ладу, форми хвилі первинного та вторинного струмів спотворюються. Суміжні форми хвиль більше перестають бути послідовними. Коли дві форми хвиль різні, то їх абсолютні інтегральні значення в більшості випадків також будуть різними. Тому абсолютні інтегральні значення зазвичай застосовуються для визначення наявності системної несправності.

Дано

$$
P=\left\{p_{1}, p_{2}, \ldots, p_{n}, p_{m}\right\}
$$

$S=\left\{s_{1}, s_{2}, \ldots, s_{n}, s_{m}\right\}$, два набори даних складаються 3 первинного та вторинного значень струму для двох суміжних форм хвиль: де $n-$ кількість зразків протягом першого циклу і $m$ - кількість зразків протягом обох циклів. Традиційно для діагностики застосовують такі особливості

$$
\begin{aligned}
& R 1=\left|\frac{\sum_{i=1}^{n} p_{i}}{\sum_{i=n+1}^{m} p_{i}}\right| ; \\
& R 2=\left|\frac{\sum_{i=1}^{n} s_{i}}{\sum_{i=n+1}^{m} s_{i}}\right|,
\end{aligned}
$$

де $\left|\sum_{i=1}^{n} p_{i}\right|$ та $\left|\sum_{i=n+1}^{m} p_{i}\right|$ - абсолютні інтегральні значення для першого та другого циклу первинного струму відповідно.

Функція $R 1$ реалізується для вимірювання подібності абсолютних інтегральних значень між двома суміжними циклами в первинному струмі. Аналогічно $R 2$ реалізується для вимірювання подібності абсолютних інтегральних значень між двома суміжними циклами у вторинному струмі. Якщо $|R 1-1|$ або $|R 2-1|$ більше, ніж заданий поріг, то 
компоненти випрямного трансформатора вважаються несправними. Однак використання абсолютних інтегральних значень для опису системи не є надійним або достатнім з наступних причин:

- по-перше, рівні абсолютні інтегральні значення двох суміжних форм хвиль не обов'язково вказують на відсутність спотворень. У випадку, показаному на рис. 3 (а) відбулося значне спотворення первинного струму, але абсолютні інтегральні значення двох суміжних форм хвиль залишилися однаковими. У цьому випадку спотворення неможливо виявити;

- по-друге, зміна абсолютних інтегральних значень суміжних форм хвиль не обов'язково вказує на несправності компонентів. Форми хвиль значно впливають на навантаження, і несправності навантаження можуть спричинити вторинні спотворення струму. На рис. 3 (б) випрямний трансформатор, що працює у системі 3 надвеликим навантаженням i нормальними компонентами при використанні для аналізу лише абсолютного інтегрального значення, виявляється несправним.
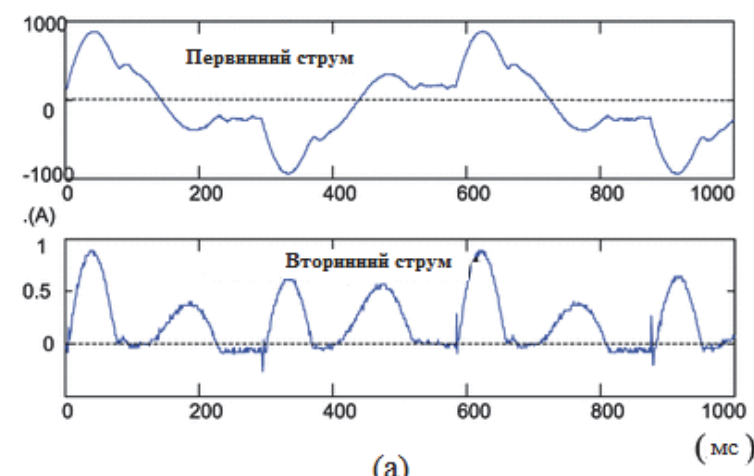

(A)
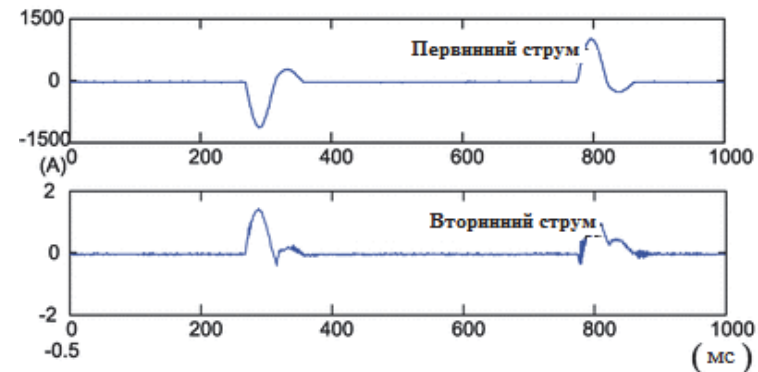

(б)

Рис. 3. Поширені прорахунки за звичайними методами: (а) - несправність випрямного моста

та (б) - нормальні форми хвиль 3 високим навантаженням

Джерело: розроблено авторами.

Всебічний та науковий аналіз поточних форм хвиль для отримання властивостей хвиль, що містять повну інформацію, дозволяє точно діагностувати несправності випрямного трансформатора.

Незважаючи на те, що небагато наукових робіт присвячено цій проблемі, підходи до аналізу хвиль, що застосовуються в таких сферах, як діагностика несправностей живлення комутаторів, для довідки може бути використана діагностика несправностей вузлів, що обертаються. В цій області зазвичай використовуються загальні методи визначення ознак, такі як WPD [11] та MCKD [12]. Ці методи забезпечують загальний спосіб отримання інформативних ознак та надають достатню інформацію для діагностики. Однак вони потребують інтенсивного обчислення та генерування не інтуїтивних особливостей.

Таким чином, більш інтуїтивний метод визначення ознак був запропонований спеціально для вирішення проблеми 3 діагностики системи, описаної в цій статті.

\section{Визначення особливостей форми струму}

Цей підхід полягає в тому, що деякі характерні змінні для часового інтервалу, такі як відношення амплітуд суміжних форм хвиль [13], час циклу, до/після нульового коефіцієнту часу [14], абсолютне інтегральне значення співвідношення суміжних форм хвиль [6] і складність форми хвилі [15], повинні бути вилучені для забезпечення точного, ефективного опису поточних форм хвиль.

$$
\text { Вирази } \quad P=\left\{p_{1}, p_{2}, \ldots, p_{n}, p_{m}\right\}
$$

$S=\left\{s_{1}, s_{2}, \ldots, s_{n}, s_{m}\right\}$ представляють форми хвиль для первинних і вторинних струмів відповідно. Ось $n$ - кількість зразків протягом першого циклу і $m$ кількість зразків протягом обох циклів. Запропонований метод вилучення функцій описує кожну форму хвилі з 11-мірним вектором, $v=\left[f_{1}, f_{2}, \ldots, f_{11}\right]$. Вектори відповідають таким характеристикам:

$f_{1}$ - відношення амплітуди первинного струму;

$f_{2}$ - відношення амплітуди вторинного струму;

$f_{3}$ - час циклу первинних і вторинних струмів;

$f_{4}$ - до/після нульового часу відношення первинного струму (перший цикл);

$f_{5}$ - до/після нульового часу відношення первинного струму (другий цикл);

$f_{6}$ - до/після нульового часу відношення вторинного струму (перший цикл);

$f_{7}-$ до/після нульового часу відношення вторинного струму (другий цикл);

$f_{8}$ - коефіцієнт абсолютного інтегрального значення первинного струму;

$f_{9}$ - коефіцієнт абсолютного інтегрального значення вторинного струму;

$f_{10}$ - складність форми хвилі первинного струму;

$f_{11}$ - складність форми хвилі вторинного струму.

Відображення наведені у розділі “Відображення особливостей”. I розрахунки цих особливостей наведені наступним чином 


$$
\begin{gathered}
f_{1}=\frac{\max \left\{\left|p_{i}\right|\right\}_{i=1}^{n}}{\max \left\{\left|p_{i}\right|\right\}_{i=n+1}^{m}} ; \\
f_{2}=\frac{\max \left\{\left|s_{i}\right|\right\}_{i=1}^{n}}{\max \left\{\left|s_{i}\right|\right\}_{i=n+1}^{m}} ; \\
f_{3}=n \cdot d,
\end{gathered}
$$

де $d$ - інтервал дискредитації. Припустимо, первинна поточна форма хвилі струму перетинає нульову точку. Потім, час перетину нульової точки $L_{1}$ для першого циклу можна обчислити так:

$$
L_{1}=\arg _{j} \max \left|\sum_{i=1}^{j} p_{i}\right|, j \in[1, n] .
$$

Таким чином, отримано вираз

$$
f_{4}=\frac{L_{1}-1}{n-L_{1}}=\frac{\arg _{j} \max \left|\sum_{i=1}^{j} p_{i}\right|-1}{n-\arg _{j} \max \left|\sum_{i=1}^{j} p_{i}\right|}, j \in[1, n] .
$$

Час перетину нульової точки для другого циклу первинного струму може бути розрахований як

$$
L_{2}=\arg _{j} \max \left|\sum_{i=n+1}^{j} p_{i}\right|, j \in[n+1, m]
$$

i "Коефіцієнт часу до/після нуля" для другого циклу первинного струму отримується так:

$$
f_{5}=\frac{m-L_{2}}{L_{2}-n}=\frac{\arg _{j} \max \left|\sum_{i=n+1}^{j} p_{i}\right|-n}{m-\arg _{j} \max \left|\sum_{i=n+1}^{j} p_{i}\right|}, j \in[n+1, m] \text {. }
$$

Аналогічно, шосту та сьому ознаки можна отримати наступним чином

$$
\begin{gathered}
f_{6}=\frac{\arg _{j} \max \left|\sum_{i=1}^{j} s_{i}\right|-1}{n-\arg _{j} \max \left|\sum_{i=1}^{j} s_{i}\right|}, j \in[1, n] ; \\
f_{7}=\frac{\arg _{j} \max \left|\sum_{i=n+1}^{j} s_{i}\right|-n}{m-\arg _{j} \max \left|\sum_{i=n+1}^{j} s_{i}\right|}, j \in[n+1, m] .
\end{gathered}
$$

Дві функції $f_{8}$ і $f_{9}$ можна обчислити як два параметри $R 1$ і $R 2$ згідно виразів (1) і (2) відповідно. Поняття складності форми хвилі, яке було запропоновано у дослідженнях [15] і доведено ії важливість для діагностування несправностей високочастотного джерела живлення, також вводиться до вилучення функції. Складність форми хвилі більш ширше пояснюється в розділі "Відображення особливостей"

$$
\begin{aligned}
f_{10} & =\sum_{i=1}^{m-1} \frac{\left|\left(p_{i}, i * d\right) \cdot\left(p_{i+1},(i+1) * d\right)\right|}{\left|\left(p_{i}, i * d\right)\right| \cdot\left|\left(p_{i+1},(i+1) * d\right)\right|} ; \\
f_{11} & =\sum_{i=1}^{m-1} \frac{\left|\left(s_{i}, i * d\right) \cdot\left(s_{i+1},(i+1) * d\right)\right|}{\left|\left(s_{i}, i * d\right)\right| \cdot\left|\left(s_{i+1},(i+1) * d\right)\right|} .
\end{aligned}
$$

\section{Відображення особливостей}

Посилаючись на рис. 4 (а), нехай амплітуди двох суміжних форм хвиль - це $A_{m 1}$ i $A_{m 2}$. Потім $f_{1}$ i $f_{2}$ вираховують відношення амплітуд для первинного і вторинного струмів відповідно. Ця функція може бути використана для оцінювання, чи $€$ пікові значення двох сусідніх форм однаковими.

Час цииклу постійний для одного й того ж поточного сигналу, незалежно від того, чи реагує система на несправність компонентів. Але для різних робочих станів час циклу $T$ може значно відрізнятися. Як показано на рис. 3 (а-б), статус спотворення роботи приводить до значної зміни часу циклу.

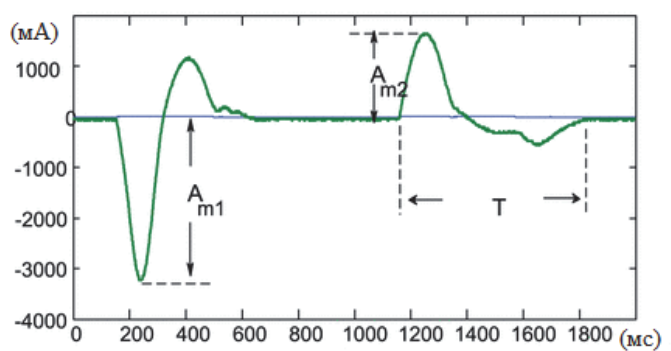

(a)

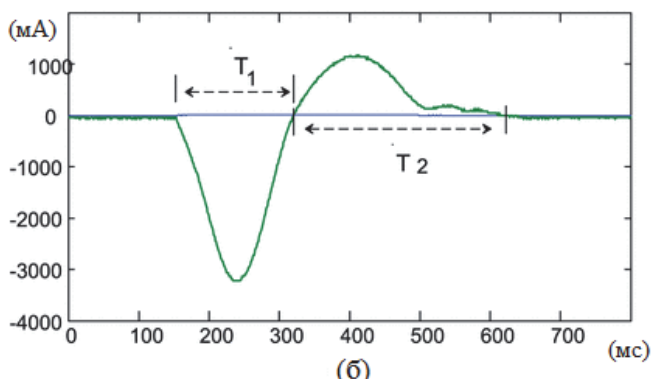

Рис. 4. Відображення деяких особливостей форми хвилі: (а) - відношення амплітуди до часу циклу i (б) - відношення часу до/після нульової відмітки Джерело: розроблено авторами.

Вирази для часу до/після нульової відмітки.

Припустимо, що форма хвилі проходить нульову відмітку, як показано на рис. 4 (б).

Співвідношення часу дорівнює відношенню $T_{1} / T_{2}$, де $T_{1}$ - це час до того, як форма хвилі пройде через нульову відмітку, а $T_{2}=T-T_{1}$ - це час проходження сигналом нульової відмітки.

Якщо форма хвилі не проходить нульової відмітки, то $T_{1}=0$. Ця особливість допомагає розрізнити форми хвиль, що зображені на рис. 5 (а-б). Дві форми хвиль мають однакові абсолютні інтегральні значення, а час циклу і амплітуди у них різні до/після нульової відмітки. 


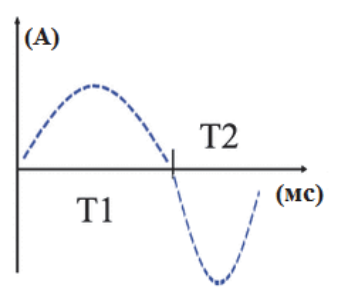

(a)

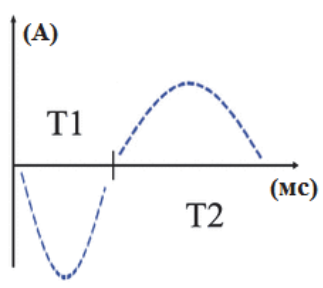

(б)
Рис. 5. Зображення співвідношення часу до/після нульової відмітки:

(a) $-\mathrm{T} 1 / \mathrm{T} 2>1$ та (б) $-\mathrm{T} 1 / \mathrm{T} 2<1$

Джерело: розроблено авторами.

Абсолютне інтегральне співвідношення суміжних форм хвиль.

Ця особливість $є$ класичним комплексним індикатором, який допомагає виявити більшість спотворень форми хвилі. Можливість використання цієї особливості було доведено в практичному проектуванні при діагностиці помилок.

Складність форми хвилі. Складна форма хвилі може мати однакові абсолютне інтегральне значення, амплітуду і період циклу у вигляді простої форми хвилі. Таким чином, складність форми хвилі слід розглядати як важливу особливість [15]. В цьому дослідженні кутові відхилення між сусідніми зразками (рис. 6) використовуються для вимірювання складності форми хвилі.

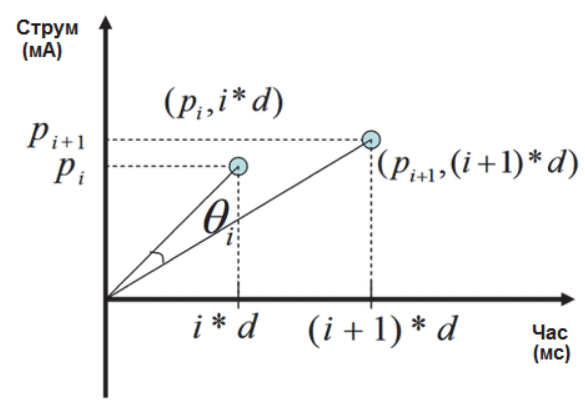

Рис. 6. Розрахунок складності форми хвилі Джерело: розроблено авторами.

Наприклад, для первинної форми хвилі струму $P=\left\{p_{1}, p_{2}, \ldots, p_{n}, \ldots, p_{m}\right\}$, у якої час вибірки послідовності $\{d, 2 * d, \ldots, n * d, \ldots, m * d\}$, косинус значення відхилення кута між $i$-м та $(i+1)$-м, ця вибірка може бути розрахована як

$$
\cos \vartheta_{i}=\frac{\left|\left(p_{i}, i * d\right) \cdot\left(p_{i+1},(i+1) * d\right)\right|}{\left|\left(p_{i}, i * d\right)\right| \cdot\left|\left(p_{i+1},(i+1) * d\right)\right|} .
$$

Потім сума всіх задіяних косинусових значень використовується для того, щоб вказати на складність форми хвилі. Тоді

$$
f_{10}=\sum_{i=1}^{m-1} \cos \vartheta_{i}=\sum \frac{\left|\left(p_{i}, i * d\right) \cdot\left(p_{i+1},(i+1) * d\right)\right|}{\left|\left(p_{i}, i * d\right)\right| \cdot\left|\left(p_{i+1},(i+1) * d\right)\right|},
$$

а функцію $f_{11}$ можна отримати аналогічним чином.
Виявлення місця несправностей випрямного трансформатора джерел живлення

Розглянемо зразки форм хвиль при різних режимах роботи системи, в тому числі при нормальних умовах роботи $(T)$, при роботі з несправним випрямлячем (міст $(F 1)$ ), та робота 3 несправним випрямлячем і трансформатором (міст $(F 2)$ ). Були відібрані як первинні, так і вторинні струми. Дані про функціонування при кожній умові роботи, які наведені вище, отримані методом виділення ознак. 3ібрані дані були нормалізовані для усунення пливу вимірювання на діагностику, рис. 7 відображає цей процес. Згодом, з використанням опрацьованих даних, були навчені багатокласні SVM класифікатори [15-16]. Коли використовувався новий зразок, класифікатори автоматично визначали належний клас найбільш ймовірної вибірки, таким чином діагностуючи несправність.

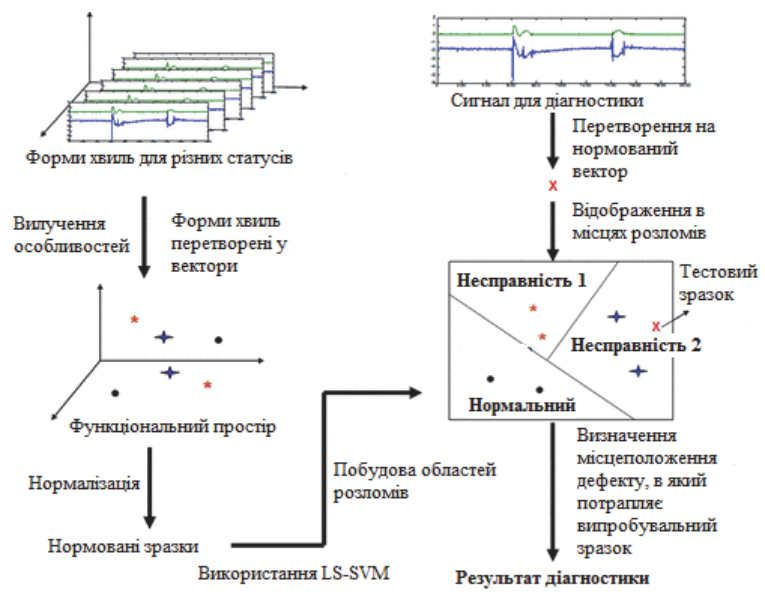

Рис. 7. Процес виявлення місця несправностей випрямного трансформатора Джерело: розроблено авторами.

Для конструювання класифікатора несправностей в LS-SVM було виконано багатоступеневе розширення класу за допомогою класичного 1-v-1 методу. Три класифікатори були сконструйовані таким чином, щоб відрізняти $F 1$ від $T, F 2$ від $T$, і $F 1$ від $F 2$. Кожен $з$ тестів вибірки був введений у всі три класифікатори, рішення яких були об'єднані для діагностики шляхом голосування.

\section{Валідаційні експерименти}

Вихідні дані та параметри експериментів

Експериментальні дані були отримані в результаті досліджень під час налаштування високочастотного джерела живлення однієї з електростанцій. Дані складалися з 24 зразків форм хвиль трьох типів: нормальні працездатні зразки (включаючи дві спроби 3 надвеликим навантаженням), несправний випрямляч 3 нормальними зразками трансформаторів, а також несправні випрямлячі та зразки трансформаторів. Випадки, коли трансформатор був несправний, але випрямляч був справний, були прийняті до уваги то- 
му, що несправність трансформатора зазвичай супроводжується несправністю випрямного моста. Чотири зразка були використані для тестування, а решта для навчання класифікаторів несправностей. Наразі досліджені два цикли форм хвиль як первинного, так і вторинного струмів кожного зразка.

Для навчання класифікатора LS-SVM було використано ядро радіальної базисної функції (RBF), типове для більшості програм [17], 3 параметрами налаштувань $\sigma^{2}=1$ i $\gamma=10$.

\section{Результати експерименту}

Класифікатори несправностей були сконструйовані шляхом об'єднання багатокласного розширення LS-SVM и 1-v-1. В експериментах первинний компонентний аналіз (PCA) було виконано для зменшення розміру функції даних. На рис. 8 зображена кластеризація несправностей: типи зразків явно розділились на окремі області, класифікатори вказують на ефективну ізоляцію несправностей. Чотири групи форм хвиль (рис. 9) були використані для тестування класифікаторів. Зроблено порівняння між діагностикою традиційним методом абсолютного інтегрального значення та запропонованим методом.

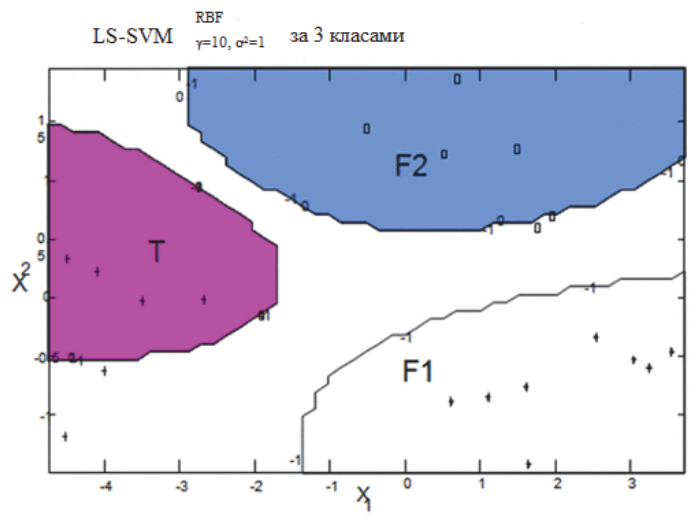

Рис. 8. Зображення кластеризації несправностей Джерело: розроблено авторами.
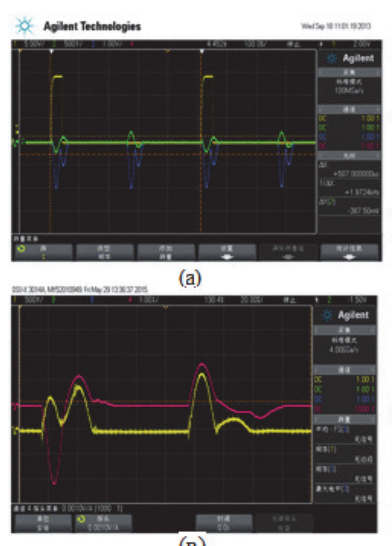

(в)

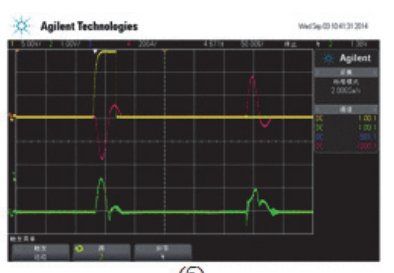

(6)

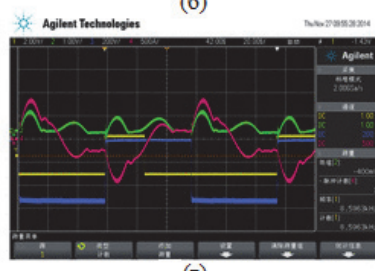

(r)
Рис. 9. Зображення форми хвилі:

(a) - нормальна форма хвилі, (б) - нормальна форма хвилі (з надвеликим навантаженням),

(в) - несправний випрямний міст зі справним трансформатором, (г) - несправний випрямний міст та трансформатор

Джерело: розроблено авторами.
Як видно 3 табл. 1, звичайний метод абсолютного інтегрального значення не ефективний при ізоляції несправностей. При формах хвиль, подібних до тих, що зображені на рис. 9 (в), несправність може бути виявлена, але не точно локалізована. Тим часом, метод має сильний зв'язуючий ефект. Як видно 3 рис. 9 (г), зображено явне спотворення первинного струму, але абсолютне інтегральне значення не має відображати цю зміну, яка приводить до не правильної класифікації. Метод вилучення особливостей, запропонований у цій статті, дозволяє уникнути цих проблем. Навчені класифікатори ефективно діагностують несправності. Для тестових зразків діагностична точність була значно вищою, ніж точність традиційного методу.

Крім того, два популярні методи вилучення функцій для аналогових схем [16; 18] або машин, що обертаються [11-12], діагностика несправностей, а саме WPD [11, 16] та MCKD [12], були введені в цій статті для побудови наборів функцій та побудови діагностичних класифікаторів. Показані обидва запропоновані методи, які були досліджені з метою забезпечення більш комплексного порівняння.

Таблиця 1

Порівняння результатів діагностування

\begin{tabular}{|c|c|c|c|c|}
\hline \multirow[b]{2}{*}{$\begin{array}{l}\text { Форми } \\
\text { хвиль }\end{array}$} & \multirow{2}{*}{ 疍 } & \multicolumn{2}{|c|}{$\begin{array}{c}\text { Діагностика звичайним } \\
\text { методом }\end{array}$} & \multirow{2}{*}{ 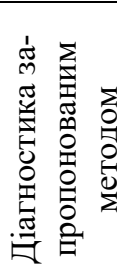 } \\
\hline & & Симптоми & 胥 & \\
\hline $\begin{array}{l}\text { Рис. } \\
9 \text { (a) }\end{array}$ & $T$ & $\begin{array}{l}\text { Немає очевидних } \\
\text { змін в жодному із } \\
\text { абсолютних інтег- } \\
\text { ральних значень } \\
\text { струму }\end{array}$ & $T$ & $T$ \\
\hline $\begin{array}{l}\text { Рис. } \\
9 \text { (б) }\end{array}$ & $T$ & $\begin{array}{l}\text { Абсолютне інтег- } \\
\text { ральне значення } \\
\text { первинного стру- } \\
\text { му без змін, оче- } \\
\text { видна зміна щодо } \\
\text { вторинного стру- } \\
\text { му }\end{array}$ & $F 1$ & $T$ \\
\hline $\begin{array}{l}\text { Рис } \\
9 \text { (в) }\end{array}$ & $F 1$ & $\begin{array}{l}\text { Очевидні зміни } \\
\text { абсолютних інтег- } \\
\text { ральних значень } \\
\text { обох струмів }\end{array}$ & $F 1 / F 2$ & $F 1$ \\
\hline $\begin{array}{l}\text { Рис. } \\
9(г)\end{array}$ & $F 2$ & $\begin{array}{l}\text { Абсолютне інтег- } \\
\text { ральне значення } \\
\text { первинного стру- } \\
\text { му не змінюється і } \\
\text { спостерігається } \\
\text { незначна зміна } \\
\text { щодо вторинного } \\
\text { струму }\end{array}$ & $T$ & $F 2$ \\
\hline
\end{tabular}

Джерело: розроблено авторами. 
Порівняння з методом WPD.

При отриманні вихідного сигналу X, WPD розкладає його на коефіцієнти апроксимації $A$ та коефіцієнти деталізації $D$ із заданим рівнем, як показано на рис. 10.

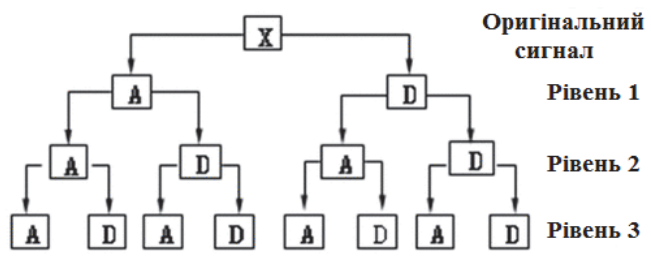

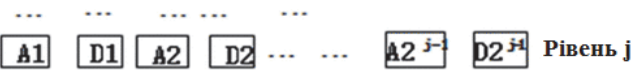

Рис. 10. Розкладання вейвлет-пакету вихідного сигналу Х з ієрархічними структурами Джерело: розроблено авторами.

Для $j$-рівня розкладання існують $2^{j-1}$ коефіцієнти апроксимації $A_{i}$ і така ж кількість деталей коефіцієнту $D_{i}$ в нижньому шарі. За допомогою цих коефіцієнтів вихідний сигнал можна реконструювати як

$$
X=\sum_{i=1}^{2^{j-1}}\left(A_{i}+D_{i}\right) * w
$$

де $w$ - обрана “вейвлет-основа". "Енергію” для кожного вузла можна обчислити за рівняннями [16]:

$$
\begin{aligned}
A C_{i} & =\left\|A_{i}\right\|_{\infty} ; \\
D C_{i} & =\left\|D_{i}\right\|_{\infty},
\end{aligned}
$$

де $\|\bullet\|_{\infty}$ - норма нескінченності, $A C_{i}$ - “енергія” для коефіцієнта апроксимації $A_{i}$, а $D C_{i}$ - це "енергія" для коефіцієнтів деталізації $D_{i}$. Усі цінності “енергії” разом створюють діагностичний набір функцій $f$ :

$$
f=\left\{A C_{i}, D C_{i}\right\}_{i=1}^{2^{j-1}} .
$$

Для проблем діагностування, де проводився моніторинг первинних та вторинних форм хвиль, формули (17-19) використовуються для генерації наборів діагностичних функцій двох сигналів.

Коли набір діагностичних функцій для первинного струму $f_{\text {певр }}$ та набір діагностичних функцій для вторинного струму $f_{\text {вmор }}$ отримані, то зразки характеристик, згенеровані на основі методу WPD, такі:

$$
v=\left\{f_{\text {nерв }}, f_{\text {втор }}\right\} .
$$

Взявши для прикладу рис. 9 (а), основний та вторинні струми можуть, відповідно, бути розкладені як на рис. 11 (а) та 11 (б) з використанням WPD на основі Haаr, рівень 2, (а) (на рис. 11 два параметри були вибрані випадковим чином).

Відповідно до формул (16-20), вибірка ознак для струмів на рис. 9 (а) може генеруватися як $(0,4529,0,0578,0,0433,0,0459,4,0400,0,2440$, $0,1235,0,0375)$. Таким чином, всі струми можуть бути подібним чином передані в функцію зразків.
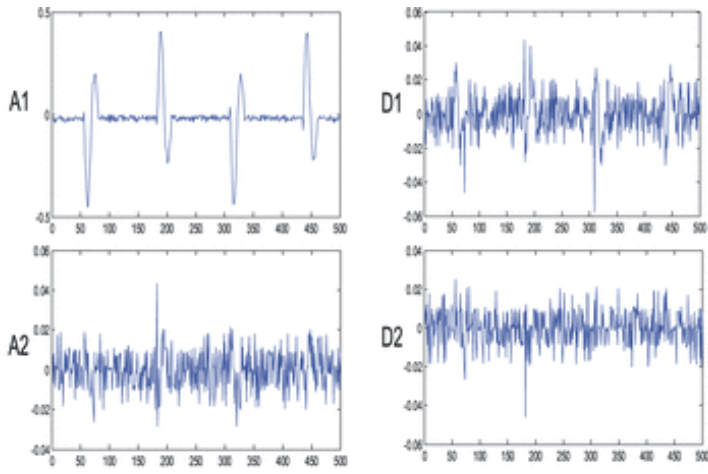

(a)
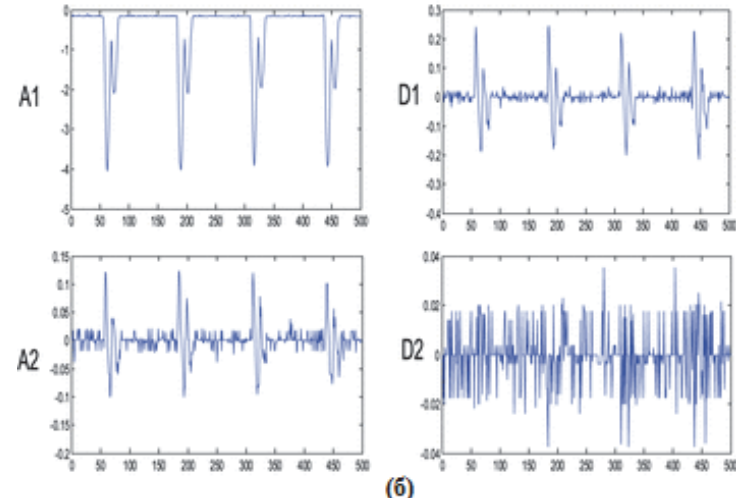

Pис. 11. WPD для рис. 9 (а) (вейвлет-основа: Haar; рівень: 2): (a) WPD для первинних струмів на рис. 9 (a)

та (б) WPD для вторинних струмів на рис. 9 (a) Джерело: розроблено авторами.

Примітка 1. Розмірне число зразків ознак дорівнює $2^{j-1}$, де $j$ - рівень розкладання.

На рис. 11 два параметри були вибрані випадковим чином.

Для більш чіткого порівняння було впроваджено пошук у сітці. WPD, на основі вейвлету $\mathrm{db} 3$ та 3 рівня розкладання (рис. 12), був використаний для вилучення характеристик 3 метою наступної діагностики несправностей на основі LS-SVM.

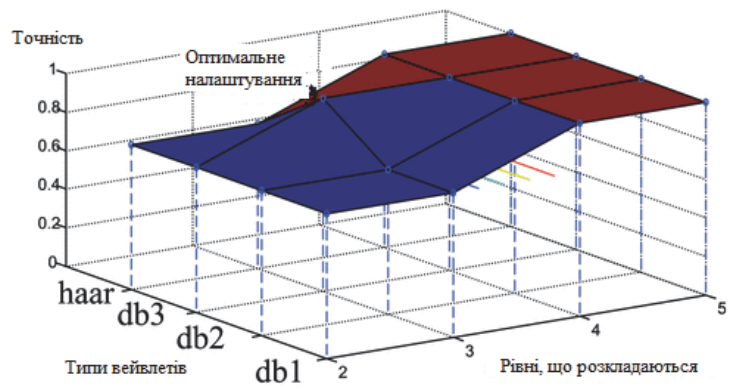

Рис. 12. Пошук оптимальних налаштувань WPD Джерело: розроблено авторами.

Отже, обидва розглянуті методи можуть точно діагностувати зразки джерел живлення, що тестуються (обидва методи досягли 100\% ефективності виявлення несправностей). Однак обчислювальні характеристики розглянутих методів діагностики $€$ різними. Отримані результати дослідження розгля- 
нутих методів діагностики несправностей випрямних трансформаторів показані в табл. 2.

Таблиця 2

Порівняння результатів обчислення

\begin{tabular}{|c|c|c|c|c|}
\hline Операція & \multicolumn{2}{|c|}{$\begin{array}{c}\text { Запропонований } \\
\text { метод }\end{array}$} & \multicolumn{2}{|c|}{$\begin{array}{c}\text { Метод на } \\
\text { основі WPD }\end{array}$} \\
\hline Розмip & \multicolumn{2}{|c|}{11} & \multicolumn{2}{|c|}{16} \\
\hline $\begin{array}{l}\text { Складність } \\
\text { обчислень } \\
\text { функцій }\end{array}$ & \multicolumn{2}{|c|}{$\mathrm{O}(\mathrm{n})$} & \multicolumn{2}{|c|}{$O(n \log n)$} \\
\hline $\begin{array}{l}\text { Складність } \\
\text { обчислень }\end{array}$ & \multicolumn{2}{|c|}{$\mathrm{O}\left(11^{*} N_{s v}\right)$} & \multicolumn{2}{|c|}{$\mathrm{O}\left(16^{*} N_{s v}\right)$} \\
\hline \multirow[t]{2}{*}{$\begin{array}{l}\text { Витрати } \\
\text { часу (c) }\end{array}$} & 量 & 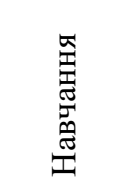 & 要 & 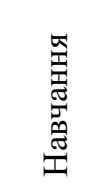 \\
\hline & 0,5868 & 0,0017 & 1,7400 & 0,0021 \\
\hline
\end{tabular}

WPD: розкладання вейвлет-пакетів

Джерело: розроблено авторами.

У табл. 2, $N_{S V}$ - це кількість векторів підтримки під час побудови класифікаторів несправностей за допомогою LS-SVM.

Порівняно з методом, заснованим на WPD, запропонований метод дозволяє отримати менші розміри вибірки та має набагато меншу складність обчислення для вилучення функцій. Отже, він витрачає менше 0,6 с на побудову класифікаторів несправностей, тоді як метод на основі WPD споживає майже 1,75 с. Це вказує на кращі показники продуктивності обчислення.

Випадки, показані на рис. 5, також обговорюються для порівняння. Наступні функції були розподілені між описаними формами хвиль на рис. 5 (а) та (б) відповідно

$$
\begin{gathered}
\left\{\begin{array}{l}
1,5 \sin (4 K \pi+t), t \in[0, \pi) ; \\
\cos (4 K \pi+0,5 t), t \in[\pi, 3 \pi] ;
\end{array}\right. \\
\left\{\begin{array}{l}
-\sin (4 K \pi+0,5 t), t \in[0,2 \pi) ; \\
1,5 \sin (4 K \pi+t), t \in[2 \pi, 3 \pi],
\end{array}\right.
\end{gathered}
$$

де $K$ - кількість циклів форми хвилі.

Запропонований метод пропонувався для двох змодельованих випадків до/після нульових коефіцієнтів часу, тобто формул (4-7). Але, як показано на рис. 13 (в), розробленому методі WPD однакова “енергія" у кожному вузлі для двох випадків [1920]. Вони дають однаковий результат характеристик (2,9335 0,2937 0,1465 0,0098). Отже, розроблений метод перевершує класичний метод WPD [19; 21] відносно виявлення випадків, показаних на рис. 5 .
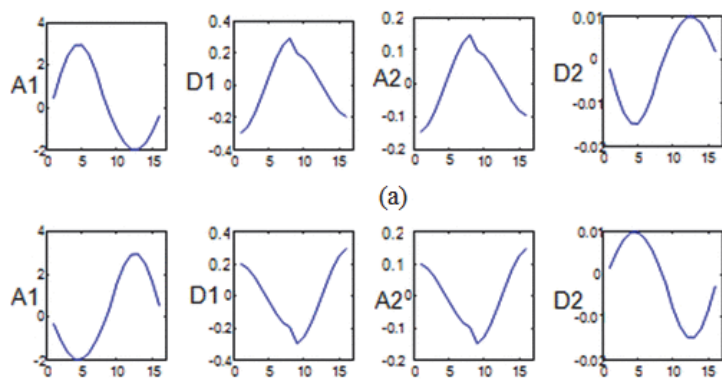

(a)
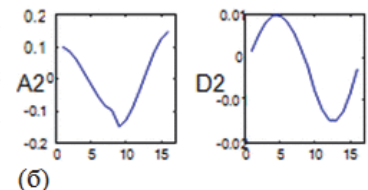

Рис. 13. WPD для рис. 5 (а) та (б) з рівнем 2 Джерело: розроблено авторами.

Порівняння з методом MCKD. По мірі наближення WPD $є$ базовим для вилучення загальних ознак, також був застосований вдосконалений метод, а саме MCKD, в можливості надання більш об'єктивного порівняння. Такий метод може вилучати ознаки несправності з форм хвиль і часто використовується при діагностиці несправностей машин, що обертаються (підшипники та редуктори) [12].

Враховуючи вихідний сигнал $X=\left\{x_{1}, x_{2}, \ldots, x_{n}\right\}$, метод MCKD намагається відновити сигнал несправності $Y=\left\{y_{1}, y_{2}, \ldots, y_{\mathrm{n}}\right\}$ застосовуючи кінцеву імпульсну характеристику (FIR) фільтр $f_{M C K D} 3 L$ зразками до $X$. Фільтри можуть бути отримані шляхом максимізації кореляції Куртозу $(\mathrm{CK})$ для $X$ :

$$
\operatorname{Max}: C K_{M}\left(T_{p}\right)=\frac{\sum_{i=1}^{n}\left(\prod_{j=0}^{M} y_{i-j T_{p}}\right)^{2}}{\left(\sum_{i=1}^{n} y_{i}^{2}\right)^{M+1}},
$$

де $T_{p}$ - період деконволюції; $M$ - порядок зсуву, і $n-$ кількість зразків у $X$.

Остаточний MCKD-фільтр у форматі FIR нарешті обирається як вилучена функція для даної форми хвилі.

При порівнянні, параметри MCKD були оптимізовані за допомогою пошуку сітки та встановлені як $M=2, T_{p}=80$ та $L=100$. Потім було досліджено ефективність діагностики вищезазначеного практичного набору даних та порівняно із запропонованим методом, як показано в табл. 3 .

\begin{tabular}{|c|c|c|c|c|}
\hline & \multicolumn{2}{|c|}{$\begin{array}{c}\text { Запропонований } \\
\text { метод }\end{array}$} & \multicolumn{2}{|c|}{$\begin{array}{c}\text { Метод на } \\
\text { основі МСKD }\end{array}$} \\
\hline $\begin{array}{l}\text { Точність } \\
\text { діагностики }\end{array}$ & \multicolumn{2}{|c|}{$100 \%$} & \multicolumn{2}{|c|}{$100 \%$} \\
\hline Розмір зразка & \multicolumn{2}{|c|}{11} & \multicolumn{2}{|c|}{100} \\
\hline \multirow[t]{2}{*}{$\begin{array}{l}\text { Витрати часу } \\
\text { (c) }\end{array}$} & 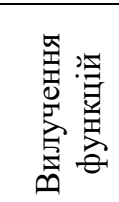 & 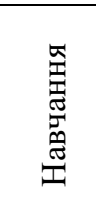 & 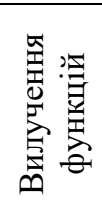 & 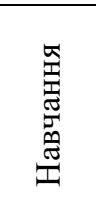 \\
\hline & 0,587 & 0,002 & 2,519 & 0,004 \\
\hline
\end{tabular}

Таблиця 3

Порівняння з методом на основі MCKD

MCKD: максимальна корельована деконволюція Куртозу.

Джерело: розроблено авторами. 


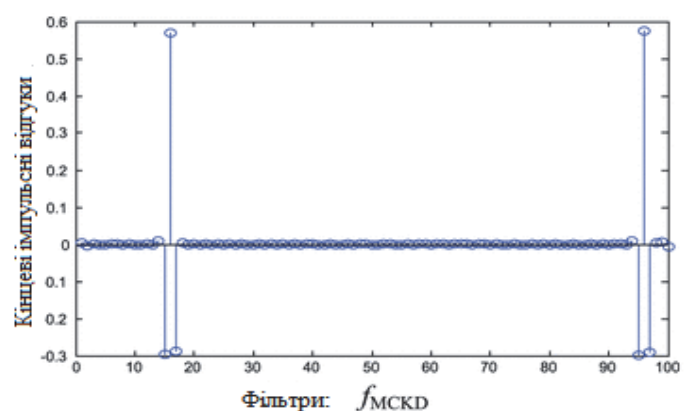

(a)

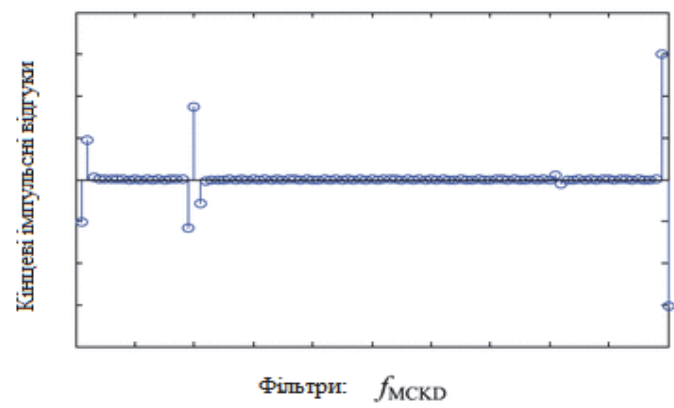

(б)

Рис. 14. Вилучення функцій для змодельованих випадків з використанням MCKD Джерело: розроблено авторами.

У методі MCKD враховуються FIR $f_{M C K D}$ як ознаки несправності. Як показано на рис. 14 (a-б), FIR у двох випадках суттєво відрізняються. Це вказує на те, що метод MCKD успішно класифікує випадки, зображені на рис. 5.

Наукова задача діагностики технічного стану $є$ вирішальною для визначення часу як для виявлення несправності згідно чотирьох методів, так і для побудови класифікатора несправностей. Запропонований метод витрачає 0,5885 с на побудову найшвидших класифікаторів несправностей. Для діагностики заданої форми хвилі запропонований метод разом порівняно із загальноприйнятим має значну перевагу.
За результатами експериментів запропонований метод дає кращу діагностичну точність, ніж звичайний метод і витрачає менше часу, ніж методи, що базуються на WPD та MCKD.

\section{Висновки}

У статті запропоновано метод, розроблений спеціально для діагностики несправностей випрямних трансформаторів. Метод використовує 11 функцій для опису системи технічного стану та реалізує систему LS-SVM до класифікаторів несправностей. За допомогою цих класифікаторів несправностей випрямних трансформаторів несправності можуть бути виявлені та локалізовані. Ефективність запропонованого методу була визначена з використанням практичних задач та змодельованих випадків.

Суттєві переваги запропонованого методу такі:

- більш висока діагностична точність визначення несправностей при роботі системи ніж за допомогою відомого інтегрального методу;

- запропоновано більш простий метод вибору для обгрунтування ознак 3 поточних форм хвиль випрямних трансформаторів для побудови класифікаторів несправностей.

Запропонований метод є перспективним для діагностики несправностей в критичних ситуаціях, в яких реалізовані форми хвиль для моніторингу технічного стану системи.

У подальших роботах пропонується дослідити застосування запропонованого методу при діагностиці випрямних трансформаторів в режимі реального часу (режимі онлайн). Так, для діагностики високошвидкісних систем в реальному часі необхідні ще швидші показники обчислень. Цей напрям надає можливість для проведення подальших досліджень.

\section{Список літератури}

1. Wang G. L., Hao Y. P., Li Y. G. Pulse current parameter evaluation of typical partial discharge models in oil. Power Syst. Tech. 2001. Vol. 25. P. 34-46.

2. Liu Z. X., Song B., Li E.W. Study of "code absence" in the IEC three-ratio method of dissolved gas analysis. IEEE Electr. Insul. M. 2015. Vol. 31. P. 6-12.

3. Lin C. E., Ling J. M., Huang C. L. An expert system for transformer fault diagnosis using dissolved gas analysis. IEEE T Power Deliv. 1993. Vol. 8. P. 231-238.

4. Wong F. K. High frequency transformer for switching mode power supplies : PhD Thesis. Brisbane: Griffith University, 2004. QLD, Australia.

5. Truntic ${ }^{`}$ M., Milanovic ${ }^{`}$ M. Voltage and current-mode control for a buck-converter based on measured integral values of voltage and current implemented in FPGA. IEEE T Power Electron. 2014. Vol. 29. P. 6686-6699.

6. Jiao S., Liu W. Novel scheme to discriminate inrush current and fault current based on integrating the waveform. Proc. Chin. Soc. Electr. Eng. 1999. Vol. 19. P. 35-38.

7. Zhu K. P., Mei T., Ye D. S. Online condition monitoring in micromilling: a force waveform shape analysis approach. IEEE T Ind. Electron. 2015. Vol. 62. P. 3806-3813.

8. Li X. L., Du R., Denkena B. Tool breakage monitoring using motor current signals for machine tools with linear motors. IEEE T Ind. Electron. 2005. Vol. 52. P.1403-1408.

9. Zheng T., Liu W. S, Xiao S. W. A new algorithm based on the mathematical morphology for power transformer protection. Proc. Chin. Soc. Electr. Eng. 2004. Vol. 24. P. 18-24. 
10. Jin L., Huang L. Y., Zheng J. N. Detection and energy feature classification of long-period precursor wave with local mean decomposition. Acta Electron. Sin. 2012. Vol. 40. P. 2439-2445.

11. Lai Z. Fault diagnosis approach of diesel engine based on wavelet packets analysis and LS-SVM. Comput. Meas. Control. 2009. Vol. 17. P. 2150-2152.

12. Mcdonald G. L., Zhao Q., Zuo M. J. Maximum correlated Kurtosis deconvolution and application on gear tooth chip fault detection. Mech. Syst. Signal Pr. 2012. Vol. 33. P. 237-255.

13. Gao M., Xu B., Zhang X. Fault location based on fault current amplitude comparison for active distribution network. Electric Power Automat Equip. 2015. Vol. 35. P. 21-25.

14. Xiang W., Hua Y., Wen J. Research on fast solid state DC breaker based on a natural current zero-crossing point. J. Modern Power Syst. Clean Energ. 2014. Vol. 2. P. 30-38.

15. Yi H., Song X. F., Jiang B. Flexible support vector regression and its application to fault detection. Acta Automat Sin. 2013. Vol. 39. P. 272-284.

16. Cui J. Wang Y. A novel approach of analog circuit fault diagnosis using support vector machines classifier. Measurement. 2011. Vol. 44. P. 281-289.

17. Hsu C. W., Chang C. C., Lin C. J. A practical guide to support vector classification. Technical report. 2003. Taipei. URL: http://www.csie.ntu.edu.tw/;cjlin/papers/guide/guide.pdf.

18. Yuan H., Chen G., Xie Y. Feature evaluation and extraction based on neural network in analog circuit fault diagnosis. $J$. Syst. Eng. Electron. 2007. Vol. 18. P. 434-436.

19. Herasimov S., Pavlii V., Tymoshchuk O., Yakovlev M. Yu., Khaustov D. Ye., Ryzhov Ye., Sakovych L., Nastishin Yu. A. Testing Signals for Electronics: Criteria for Synthesis. Journal of Electronic Testing. 2019. Vol. 35. Is. 3(148). P. 349-357. https://doi.org/10.1007/s10836-019-05798-9.

20. Herasimov S., Roshchupkin E., Kutsenko V., Riazantsev S., Nastishin Yu. Statistical analysis of harmonic signals for testing of Electronic Devices. International Journal of Emerging Trends in Engineering Research. 2020. Vol. 8 (7). P. 3791-3798. https://doi.org/10.30534/ijeter/2020/143872020.

21. Herasimov S., Borysenko M., Roshchupkin E., Hrabchak V. I., Nastishin Yu. A. Spectrum Analyzer Based on a Dynamic Filter. Journal of Electronic Testing. 2021. Vol. 37. P. 357-368. https://doi.org/10.1007/s10836-021-05954-0.

\section{Відомості про авторів:}

\section{Яровий Віталій Сергійович}

ад'юнкт

Військового інституту телекомунікацій та інформатизації ім. Героїв Крут,

Київ, Україна

https://orcid.org/0000-0002-8239-1150

\section{Радзівілов Григорій Данилович}

кандидат технічних наук доцент

заступник начальника

Військового інституту телекомунікацій та інформатизації ім. Героїв Крут з наукової роботи,

Київ, Україна

https://orcid.org/0000-0002-6047-1897

\section{Герасимов Сергій Вікторович}

доктор технічних наук професор

Харківського національного університету

Повітряних Сил ім. І. Кожедуба,

Харків, Україна

https://orcid.org/0000-0003-1810-0387

\section{Кірвас Валерія Вікторівна}

науковий співробітник

Харківського національного університету

Повітряних Сил ім. І. Кожедуба,

Харків, Україна

https://orcid.org/0000-0001-5310-6587

\section{Information about the authors:}

\author{
Vitalii Yarovyi \\ Post-Graduate \\ of Military Institute of telecommunications \\ and information technologies named after Heroes of Kruty, \\ Kyiv, Ukraine \\ https://orcid.org/0000-0002-8239-1150
}

\section{Grygoriy Radzivilov}

$\mathrm{PhD}$ in Engineering Associate Professor

Deputy Head of Military Institute of telecommunications and information technologies named after Heroes of Kruty in Science,

Kyiv, Ukraine

https://orcid.org/0000-0002-6047-1897

\author{
Sergey Herasimov \\ Doctor of Engineering Science Professor \\ of Ivan Kozhedub Kharkiv National \\ Air Force University, \\ Kharkiv, Ukraine \\ https://orcid.org/0000-0003-1810-0387
}

\author{
Valeriya Kirvas \\ Researcher \\ of Ivan Kozhedub Kharkiv National \\ Air Force University, \\ Kharkiv, Ukraine \\ https://orcid.org/0000-0001-5310-6587
}




\title{
ДИАГНОСТИКА НЕИСПРАВНОСТЕЙ ВЫПРЯМИТЕЛЬНЫХ ТРАНСФОРМАТОРОВ ВЫСОКОЧАСТОТНЫХ ИСТОЧНИКОВ ПИТАНИЯ НА ОСНОВЕ ОПРЕДЕЛЕНИЯ ОСОБЕННОСТЕЙ ТОКА
}

\author{
В.С. Яровой, Г.Д. Радзивилов, С.В. Герасимов, В.В. Кирвас
}

Исследуются особенности обнаружения неисправностей выпрямительных трансформаторов высокочастотных источников питания. Показано, что выпрямительные трансформаторы являются ключевыми компонентами высокочастотных источников питания. Обосновано, что формы волны выходного тока выпрямительных трансформаторов играют важную роль в диагностике неисправностей источников питания высокой частоты. Цель статьи состоит в усовершенствовании метода диагностики неисправностей выпрямительных трансформаторов высокочастотных источников питания. С использованием разработанных классификаторов неисправностей выпрямительных трансформаторов высокочастотных источников питания возможные неисправности могут быть оперативно обнаружены и локализованы.

Ключевые слова: диагностика неисправностей, высоковольтный источник питания высокой частоты, выбор функции, мониторинг.

\section{FAULT DIAGNOSIS FOR RECTIFIER TRANSFORMERS OF HIGH-FREQUENCY POWER SUPPLIES BASED ON CURRENT WAVEFORM FEATURE EXTRACTION}

\author{
V. Yarovyi, G. Radzivilov, S. Herasimov, V. Kirvas
}

The features of detecting faults in rectifier transformers of high-frequency power supplies are investigated. Rectifier transformers are shown to be key components of high frequency power supplies. It is substantiated that the waveforms of the output current of rectifier transformers play an important role in the diagnosis of faults in high-frequency power supplies. Usually, the integral value of the current waveform is analyzed in the rectifier transformer fault diagnosis. The waveforms are significantly affected by the load, which in combination with faults complicates the process of diagnosing the technical condition. Conventional methods cannot determine with high accuracy possible faults due to high errors. The purpose of the article is to improve the method for diagnosing faults in rectifier transformers of high-frequency power supplies. A method developed specifically for diagnostics of rectifier transformer faults is proposed. A complex output current waveform can have the same absolute integral value, amplitude, and cycle period as a simple waveform. The complexity of the waveform should be considered an important feature. In this study, the angular deviations between adjacent current characteristics are used to measure the complexity of the waveform. The method uses functions to describe the technical condition system and implements a system for fault classifiers. With these fault classifiers, rectifier transformers faults can be detected and localized. The effectiveness of the proposed method was determined using practical problems and simulated cases. Based on the experimental results, the proposed method gives better diagnostic accuracy than the conventional method. This method takes less time than known diagnostic methods. In further works, it is proposed to investigate the application of the proposed method in diagnostics of rectifier transformers in real time (online).

Keywords: fault diagnosis, high voltage high frequency power supply, feature extraction, monitoring. 